\title{
Causes of Change Orders in Construction Projects
}

\author{
Walid M. A. Khalifa \\ Civil Engineering Department \\ Hail University, Saudi Arabia and \\ Fayoum University, Egypt \\ khalifawalid@yahoo.com
}

\author{
Ibrahim Mahamid \\ Civil Engineering Department \\ Prince Mugrin University \\ Medina, Saudi Arabia \\ imahamid@ymail.com
}

\begin{abstract}
Change orders are usually issued to cover variations in the scope of work, material quantities, design errors, and unit rate changes. This study discusses variations in public construction projects in Saudi Arabia by investigating their causes, studying their effects on the project, identifying the ben eficial parties, and suggesting remedies to alleviate the related problems. Tasks included conducting a field survey via a questionnaire. It was determined that the top five causes of change orders from contractors' view are: owner's additional works, errors, and omissions in design, lack of coordination between construction parties, defective workmanship, and owner financial difficulties.
\end{abstract}

Keywords-change orders; variation orders; construction; contractors; consultants

\section{INTRODUCTION}

In the last thirty years, Saudi Arabia has experienced a huge growth in the field of construction, due to the wealth created by the oil industry and the economic impetus it has given the country. This has resulted in very rapid growth and transformations during that period. The high living standards of the people of Saudi Arabia have generated many manufacturing and building employment opportunities. The growth of towns accelerated as a result of high population growth. Large and complex projects have been built, attracting contractors and construction companies from all over the world. Most of those contractors and their companies lack sufficient understanding of the social, cultural and physical environment of Saudi Arabia. This situation coupled with inexperienced owners has led to inadequate designs resulting in many changes to plans, specifications, and contract terms. The construction industry and its parties are associated with high degree of risk. Risk in construction has been the object of attention because of time and cost overruns associated with construction projects [1]. The change orders were proved to be one of the main factors leading to cost and time overrun in construction projects. These changes are inevitable in any construction project. Needs of the owner may change in the course of design or construction, market conditions may impose changes to the parameters of the project, and technological developments may alter the design and the choice of the engineer. The engineer's review of the design may bring about changes to improve or optimize the design and hence the operation of the project. Further, errors and omissions in engineering or construction may force a change. These and other factors necessitate changes that are costly and Corresponding author: Walid M. A. Khalifa generally un-welcomed by all parties. Consideration must be given to this problem from the early stages of the project. A contract change clause is added to define the way that owner, consultant, and contractor will handle changes. A procedure must be set to process a change from its conceptual development until it materializes in the field. Given the fact that an adversarial atmosphere usually exists between the parties in the construction industry, a change must be managed well in order to minimize its cost, schedule and consequential effects that can lead to enormous cost and schedule overruns.

A change order is a written order to the contractor, signed by the owner, and issued after execution of the contract, authorizing a change in the work or an adjustment in contract sum or contract time. Changes in designs and contract documents usually lead to change in contract price or schedule. Changes also increase the possibility of contractual disputes. In general, changes present problems to all parties involved in the construction process. There are many reasons for issuing construction change orders in large building construction contracts. It might be a result of further development of the owner's requirements. It can be a result of non-availability, slow delivery of required materials or correction of contract document errors and omissions. Identifying the causes of change orders is very important in order to avoid potential changes in future projects or to minimize their effects. The aim of this research is therefore to study the causes of construction change orders in construction projects in Hail in Saudi Arabia. This study will assist both owners and contractors to plan effectively before starting a project and during the design phase to minimize and control changes and change effects. This study will also lay the foundation for further research on the subject. The objectives of the study can be divided into three categories. The first is to identify the main causes of construction change orders in Saudi Arabia. The second is to identify the severity of those causes. The third is to suggest remedies to alleviate related problems.

\section{LITERATURE REVIEW}

Change orders have long been an inherent part of the construction industry. The execution of a construction project without a change is a rare occasion. Change normally arises as a result of some causes attributed to the different parties involved in the project execution. Upon acknowledging its existence, the change - or variation is formally regularized by the issuance of a change order which is a document describing 
the scope of the change and its impact on both cost and/or time. If no agreement is reached between the parties of the project on the change, it turns into a claim or dispute that may negatively affect the execution of the project and curtail its chances of successful completion. Change order is work added to or deleted from the original scope of work of a contract which alters the original contract amount or completion date [2]. The change has been defined as any deviation from an agreed upon well-defined scope and schedule [3]. The words "Change Order" conjure strong feelings of negativity for all involved in construction projects. Owners do not like them because they generally feel they are paying for the mistakes of others. Contractors may believe that change orders disrupt workflow and require additional paperwork and time. In other cases, contractors would find in change orders a mean to improve their outcome of the project. However, it is generally accepted that consultants, contractors, and owners agree that projects would be better without change orders.

Change orders strain the relationships of owners, engineers, contractors, subcontractors, and others involved in the construction process, also adding cost and schedule delay. Changes on one project can also affect other unrelated projects by tying up resources that are committed elsewhere. Negative relationships between the parties are another by-product of changes on a project. Not only workflow is disrupted, but also trying to get quick responses quotes, shop drawings, and many other things required to get back schedule causes a strain on working relationships [4]. Authors in [5] investigated 21 causes and 11 potential impacts of change orders. Nine practices were reported to management and control of change orders. The study identified 11 important causes and 7 important impacts. It was further concluded that the consultant is the most responsible party for change orders. The overall average increase in total cost of construction projects due to change orders was found to be $11.3 \%$. The research concluded that change of project scope due to owner requirements is the most important cause and cost overruns are the most important impacts of change orders in those projects. Changes during construction of projects are inevitable in most construction projects and change orders are issued to correct or modify the original design or scope of work. The corrections or modifications are carried out for many reasons including changes in scope made by the client and as a result of change requests made by the consultant due to design errors or new findings. The contractor makes use of the different interpretations of the contract clauses or loose ends in the scope or design to improve his profit margin. Most of change orders issued during the construction period are major causes of time and cost overruns, disruption, and disputes. In some cases, change orders cause confusion and lead to detrimental effect on the environment. Yet, no unique method is available for avoiding or managing them effectively. The conventional approach is to include a percentage of the project cost as a contingency in the contract budget for their occurrence.

Authors in [6] studied the influencing factors on 31 highrise projects in Indonesia and found that design changes is one of the most important factors causing time overrun. Authors in [7] conducted a survey to determine and evaluate the relative importance of the significant factors causing delays in Hong
Kong construction projects. The survey covered 83 previously identified delay factors. The study classified the reasons for delays based on the role of the parties in the local construction industry (clients, consultants or contractors) and the type of projects. The results indicated 5 principal causes of delays: poor site management and supervision, unforeseen ground conditions, low speed of decision making involving all project teams, client-initiated variations, and necessary variations of works. Author in [8] found that user changes are one of the main causes of delay in 130 public projects in Jordan. Authors in [9] used a survey to identify the most important causes of delays in construction projects. The research revealed that the most important factors were: owner interference, inadequate contractor experience, financing and payments, labor productivity, slow decision making, improper planning, and subcontractors. Author in [10] reported 5 key elements that burden projects: payments, authority, change orders, work schedule, and contract documents. Author in [11] divided the causes of delay into two broad categories: excusable delays and nonexcusable delays. Excusable delays were more oriented to the client or consultant causes, while nonexcusable delays were related to the contractor. Design change was mentioned as a cause in excusable delays. The research suggested a list of remedies for the causes of both categories. Authors in [12] carried out field survey and identified 6 construction conflicting factors pertinent in Korean context. Change order was the third factor causing conflict in construction projects. Authors in [13] conducted a questionnaire survey in Malaysia and identified 10 causes of delay. The first three causes were: contractor's improper planning, contractor's poor site management, and inadequate contractor's experience. Authors in [14] reported that changes in design as well as defects and correction in design as factors that resulted in cost and time overruns. Authors in [15] conducted a field survey on time performance of different construction projects in Saudi Arabia. They identified 73 causes of delay in the 76 projects surveyed, but the most common cause of delay identified by all three parties (clients, consultants, and contractors) was the "change order". Authors in [16] studied the causes of 1,038 change orders issued for a national highway project in Taiwan. Their study revealed that the design insufficiency of geologic survey, site survey, and planning are the major causes of change orders.

A method that can be used to solve potential lawsuit problems caused by change orders in construction projects was provided in [17]. The method developed the Hybrid ANN-CBR Model (HACM), the AI branches of Artificial Neural Networks (ANN) and Case Based Reasoning (CBR). The research was based on the litigation archives evaluating 31 cases. It is confirmed that the model HACM performs well especially for those medium sized construction projects. Authors in [18] studied the variations in public construction projects in Oman. The study determined that the client's additional works and modifications to design were the most important factors causing change orders, followed by the nonavailability of construction manuals and procedures. The suggested remedial actions were the revision of registration of consulting offices would be the most important action followed by establishing standard documents for design procedures and building a national database about soil conditions and services. 
Authors in [19] investigated the change orders for public and private construction projects in Kuwait using a questionnaire surveying comprising 385 engineers representing the construction industry for the owners, contractors, and consultants. The results of the questionnaire indicated that the owner is the most responsible party causing changes due to change of plans by the owner which cause increase in project's cost. The study put the first control as checking all changes to design documents. Authors in [20] identified the most common factors responsible for cost escalations in construction industry in Pakistan using a questionnaire survey for clients, consultants, and constructors. The study results showed that financial problems, slow payments, and inflation were the topranked identified factors responsible for cost escalation in the construction industry of Pakistan. Authors in [21] adopted a quantitative approach to find the main causes of time overrun in the construction of building project and its possible mitigation measures. The study revealed that the main causes of time overrun in construction projects can be concluded as the financial issues faced by the contractor, contractor's inexperience, weather impacts, late delivery of materials, mistakes in design, shortage of skilled labor, incompetent subcontractor and mistakes in time estimation. Mitigation measures were also proposed.

\section{RESEARCH METHODOLOGY}

Twenty one factors that might affect orders in construction projects were defined through a detailed literature review. The factors were tabulated into a questionnaire form. The draft questionnaire was discussed with some parties involved in construction projects to evaluate and modify its content. Recommendations for minimizing change orders in construction projects were emphasized in view of the results of the study.

\section{A. Questionnaire Design}

The questionnaire was divided into two main parts. Part I was related to general information. Contractors and consultants were further requested to answer questions pertaining to their experience in the construction industry. Part II included the list of the identified causes of change orders in construction projects as shown in Table I.

TABLE I. LIST OF CHANGE ORDER CAUSES

\begin{tabular}{|c|c|c|c|}
\hline No. & Cause of change orders & No. & Cause of change orders \\
\hline 1 & Owner's additional works & 12 & Value engineering \\
\hline 2 & Error and omissions in design & 13 & Unavailability of skills \\
\hline 3 & Lack of coordination & 14 & Defined project objective \\
\hline 4 & Defective workmanship & 15 & Differing site conditions \\
\hline 5 & Owner financial difficulties & 16 & New government regulations \\
\hline 6 & Change of plans by owner & 17 & Unavailability of equipment \\
\hline 7 & Contractor financial difficulties & 18 & $\begin{array}{c}\text { Substitution of material or } \\
\text { procedures }\end{array}$ \\
\hline 8 & Changes in design & 19 & $\begin{array}{c}\text { Conflict between contract and } \\
\text { document }\end{array}$ \\
\hline 9 & Safety considerations & 20 & Technology changes \\
\hline 10 & $\begin{array}{c}\text { Contractor desire to improve his } \\
\text { financial conditions }\end{array}$ & 21 & Weather conditions \\
\hline 11 & Owner change of schedule & & \\
\hline
\end{tabular}

For each factor a question was asked: what is the degree of severity of this cause on change orders? Degree of severity was categorized as follows: very high, high, moderate, low and very low (on 5 to 1 point scale).

\section{B. Data Analysis}

The information collected from the questionnaire was analyzed statistically in Excel. The statistical methods that were used for calculating and presenting the survey results are discussed below.

\section{1) Ranking}

The suggested change orders causes in construction projects are ranked by the measurement of the severity index [22]. Regarding the severity index, a formula is used to rank causes of cost overrun based on their impact level as identified by the participants:

$$
\text { Severity Index }(\%)=\sum \mathrm{a}(\mathrm{n} / \mathrm{N}) * 100 / 5
$$

where, $a$ is the constant expressing weighting given to each response (ranges from 1 for very low up to 5 for very high), $n$ is the frequency of the responses and $\mathrm{N}$ is the total number of responses. Accordingly, if all participants answer one factor to be of "no influence", then the severity index is 0 , which means that this factor is not relevant. On the other hand, if all answer that it is of "very high influence", then the severity index is 100 , which means that this factor is very highly relevant. Table II shows the possible ranges for the severity index and the corresponding impact level. The severity index for all causes was calculated according to (1) from contractors' and consultants' view.

TABLE II. SEVERITY INDEX SCALE AND THE CORRESPONDING IMPACT LEVEL

\begin{tabular}{|c|c|c|c|c|c|c|}
\hline $\begin{array}{c}\text { Range } \\
\text { (\%) }\end{array}$ & 0 & $<20$ & $20-40$ & $40-60$ & $60-80$ & $80-100$ \\
\hline $\begin{array}{c}\text { Impact } \\
\text { level }\end{array}$ & $\begin{array}{c}\text { no } \\
\text { influence }\end{array}$ & $\begin{array}{c}\text { very } \\
\text { low }\end{array}$ & low & moderate & high & $\begin{array}{c}\text { very } \\
\text { high }\end{array}$ \\
\hline
\end{tabular}

\section{2) Importance Rank Correlation}

The correlation coefficient is used to measure the extent of which two variables are linearly related. Spearman rank correlation factor was used to measure the degree of agreement between contractors and consultants on the severity and frequency index for factors affecting quality in construction projects. Equation (2) was used for the calculation of the spearman rank correlation [23]:

$$
r_{s}=1-\left[6 * \sum d^{2} /\left(n^{3}-n\right)\right]
$$

where $r_{s}$ is the Spearman rank correlation coefficient (the agreement between contractors and consultants), $\mathrm{d}$ is the difference between the ranks on one variable and the ranks on another variable, and $\mathrm{n}$ is the number of causes.

\section{RESULTS PRESENTATION AND ANALYSIS}

\section{A. General Characteristics of Respondents}

The questionnaire was sent out to a total of 40 contractors and 40 consultants, asking their contribution in ranking the identified 21 causes in terms of severity using an ordinal scale. 
A total of 30 contractors and 25 consultants filled the questionnaire with response rates of $75 \%$ and $63 \%$ respectively. Participating consultants and contractors have an average of more than 10 years of experience. Simple random sampling was used to select the participants from an available list.

\section{B. Ranking of Change Orders Causes}

The causes under each group are ranked by the measurement of severity according to (1). The severity index and ranking of all investigated change orders causes in construction projects in Saudi Arabia from contractors' view and consultants' view are listed in Table III. The results show that both contractors and consultants ranked the followings as the top causes of change orders in construction projects in Saudi Arabia:

\section{Owner's additional works}

2. Error and omissions in design

3. Lack of coordination

TABLE III. RANKING OF CHANGE ORDERS CAUSES

\begin{tabular}{|l|c|c|c|c|}
\hline \multirow{2}{*}{ Cause } & \multicolumn{2}{c|}{ Contractors' view } & \multicolumn{2}{c|}{ Consultants' view } \\
\cline { 2 - 5 } & $\begin{array}{c}\text { Severity } \\
\text { index }\end{array}$ & Rank & $\begin{array}{c}\text { Severity } \\
\text { index }\end{array}$ & Rank \\
\hline Owner's additional works & 82.03 & 1 & 86.67 & 1 \\
\hline $\begin{array}{l}\text { Error and omissions in } \\
\text { design }\end{array}$ & 79.23 & 2 & 83.33 & 2 \\
\hline Lack of coordination & 77.69 & 3 & 81.33 & 3 \\
\hline Defective workmanship & 76.14 & 4 & 67.33 & 7 \\
\hline Owner financial difficulties & 72.09 & 5 & 72.00 & 4 \\
\hline Change of planes by owner & 64.81 & 6 & 66.67 & 10 \\
\hline $\begin{array}{l}\text { Contractor financial } \\
\text { difficulties }\end{array}$ & 62.39 & 7 & 65.33 & 13 \\
\hline Change in design & 61.15 & 8 & 68.00 & 6 \\
\hline Safety consideration & 59.68 & 9 & 67.33 & 8 \\
\hline $\begin{array}{l}\text { Contractor desire to improve } \\
\text { his financial conditions }\end{array}$ & 58.91 & 10 & 66.67 & 11 \\
\hline Owner change of schedule & 58.52 & 11 & 67.33 & 9 \\
\hline Value engineering & 56.29 & 12 & 66.00 & 12 \\
\hline Unavailability of skills & 55.28 & 13 & 62.67 & 17 \\
\hline Defined project objective & 51.14 & 14 & 55.33 & 21 \\
\hline Differing site conditions & 51.06 & 15 & 70.00 & 5 \\
\hline New government regulations & 50.18 & 16 & 65.33 & 14 \\
\hline Unavailability of equipment & 48.16 & 17 & 61.33 & 20 \\
\hline $\begin{array}{l}\text { Substitution of material or } \\
\text { procedures }\end{array}$ & 48.12 & 18 & 64.00 & 15 \\
\hline $\begin{array}{l}\text { Conflict between contract } \\
\text { and document }\end{array}$ & 46.74 & 19 & 63.33 & 16 \\
\hline Technology change & 46.32 & 20 & 62.67 & 18 \\
\hline Weather conditions & 46.25 & 21 & 62.00 & 19 \\
\hline
\end{tabular}

\section{Statistical analysis}

Statistical analysis and participants' responses indicate that contractors and consultants highly agree on the severity of these causes e.g. owner's additional works, which is the top ranked cause, has standard deviation of 0.79 and 0.79 from contractors and consultants, respectively. It also has coefficient of variation of $17 \%$ and $22.69 \%$ from contractors and consultants respectively. Responses also show that most of the participants specify it as high affecting cause (i.e. $75 \%$ of the participating consultants and $80 \%$ of the participating contractors said that it has high to very high impact level). Table IV presents the statistical analysis for the severity responses of change orders causes as assessed by contractors and consultants. The Table contains the computation of the standard deviation $\left(\mathrm{S}_{\mathrm{n}}\right)$ and coefficient of variation (C.V.). Table IV shows that the $S_{n}$ and C.V. have reasonable values. A visual indication got from the scatter diagram (Figure 1) is that the data have good compactness, indicating that there is a good data consistency and agreement on the severity of the identified causes. Figure 2 shows the $S_{n}$ of the identified causes for consultants' responses. The Figure shows good data compactness and a good internal consistency and agreement on the severity of the identified causes. Visual comparison between Figures 1 and 2 indicate that the contractors' data has better compactness than the consultants' data and so there is better internal agreement and consistency in the contractors input than the consultants'.

TABLE IV. STATISTICAL ANALYSIS FOR THE SEVERITY OF CHANGE ORDERS CAUSES

\begin{tabular}{|l|c|c|c|c|}
\hline \multirow{2}{*}{ Cause } & \multicolumn{2}{|c|}{$\begin{array}{c}\text { Contractors' } \\
\text { responses }\end{array}$} & \multicolumn{2}{c|}{$\begin{array}{c}\text { Consultants' } \\
\text { responses }\end{array}$} \\
\cline { 2 - 5 } & $\mathbf{S}_{\mathrm{n}}$ & $\mathbf{C . V . ( \% )}$ & $\mathbf{S}_{\mathrm{n}}$ & C.V.(\%) \\
\hline Owner's additional works & 0.79 & 17.00 & 0.78 & 22.69 \\
\hline $\begin{array}{l}\text { Error and omissions in } \\
\text { design }\end{array}$ & 0.98 & 34.40 & 0.68 & 30.50 \\
\hline Lack of coordination & 1.02 & 20.27 & 1.04 & 36.78 \\
\hline Defective workmanship & 0.81 & 40.33 & 1.34 & 38.14 \\
\hline Owner financial difficulties & 0.98 & 24.07 & 0.80 & 31.35 \\
\hline Change of planes by owner & 1.04 & 21.29 & 0.86 & 31.18 \\
\hline $\begin{array}{l}\text { Contractor financial } \\
\text { difficulties }\end{array}$ & 0.74 & 21.35 & 0.76 & 26.80 \\
\hline Change in design & 0.71 & 30.17 & 0.76 & 23.06 \\
\hline Safety consideration & 0.83 & 28.77 & 0.67 & 23.59 \\
\hline $\begin{array}{l}\text { Contractor desire to improve } \\
\text { his financial conditions }\end{array}$ & 1.17 & 34.28 & 0.78 & 36.74 \\
\hline Owner change of schedule & 0.89 & 31.14 & 0.63 & 31.27 \\
\hline Value engineering & 1.04 & 33.09 & 1.07 & 39.33 \\
\hline Unavailability of skills & 1.23 & 37.25 & 0.64 & 40.19 \\
\hline Defined project objective & 0.76 & 28.83 & 0.74 & 38.48 \\
\hline Differing site conditions & 0.91 & 53.76 & 0.74 & 43.13 \\
\hline New government regulations & 0.95 & 47.34 & 1.00 & 33.87 \\
\hline Unavailability of equipment & 1.00 & 35.11 & 0.86 & 34.21 \\
\hline $\begin{array}{l}\text { Substitution of material or } \\
\text { procedures }\end{array}$ & 0.74 & 26.79 & 0.79 & 26.80 \\
\hline $\begin{array}{l}\text { Conflict between contract } \\
\text { and document }\end{array}$ & 1.11 & 36.59 & 0.70 & 39.45 \\
\hline Technology change & 0.87 & 41.20 & 1.10 & 37.98 \\
\hline Weather conditions & 0.98 & 26.99 & 0.85 & 32.13 \\
\hline
\end{tabular}

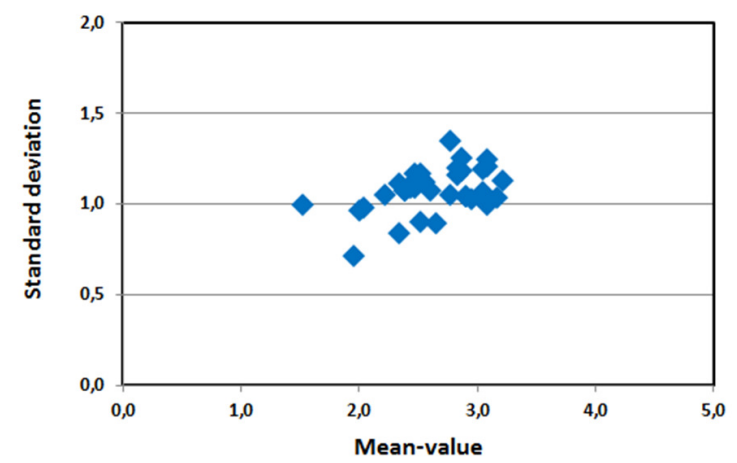

Fig. 1. Mean value vs. standard deviation for contractors' responses 


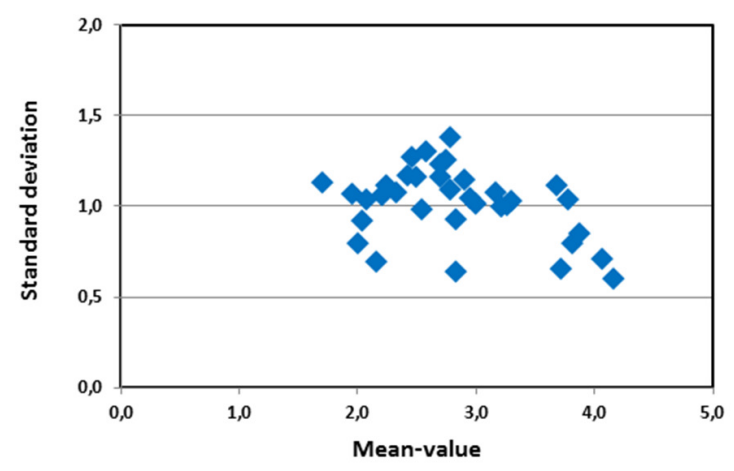

Fig. 2. Mean value vs. standard deviation for consultants' responses

\section{Rank Correlation}

Spearman correlation was used to determine the association among the parties included in this study. This test is used to find and compare how well the contractors and consultants agree on the severity of the causes affecting change orders construction projects. By applying (2), then:

$$
\mathrm{r}_{\mathrm{s}}=1-\left((6 * 5808) /\left(52^{3}-52\right)\right)=0.75
$$

The value of $r_{s}$ is close to +1 which indicates good agreement between consultants and contractors on the ranking of change orders causes.

\section{SUMMARY AND RECOMMENDATIONS}

The causes of change orders in construction projects in Saudi Arabia were discussed in a field survey which studied the severity of the causes of change orders. Twenty one causes of change orders were identified. The field survey included 30 contractors and 25 consultants. The top five severe causes of change orders as seen from contractors' view were:

1. Owner's additional works

2. Error and omissions in design

3. Lack of coordination

4. Defective workmanship

5. Owner financial difficulties

The top five severe causes of change orders as seen from consultants' views were:

1. Owner's additional works

2. Error and omissions in design

3. Lack of coordination

4. Owner financial difficulties

5. Differing site conditions

The value of the Spearman's rank correlation coefficient of $75 \%$ indicates that there is relative good agreement between contractors and consultants on the severity rank of the change orders causes. The statistical analysis of the data shows the following: (1) No participant response specified any cause with no influence on the change orders and (2) no causes had severity index less than $30 \%$. These indicate that the identified causes are highly relevant to the problem of change orders in construction projects in Saudi Arabia. In spite of the good data consistency and agreement between the surveyed participants on the severity of the identified change orders causes, there are some sources of uncertainty, these might be:

- Misunderstanding of the questions by the respondents.

- Answering from different backgrounds, especially for consultants who have experience in many construction types such as building, utilities, etc. and so they may be biased to a construction type.

The following remedial steps are recommended to be followed in order to improve the management of construction projects in Saudi Arabia:

- A standard manual with a check list for design of projects should be developed to regulate all stages/steps including feasibility study, design, tendering, tender evaluations, and project awarding. This document should be implemented by a specialized governmental unit.

- A specialized national technical unit should be established to study and evaluate overall construction practices in Saudi Arabia, to establish a construction procedure manual, and to follow-up on its implementation.

- A national database system about soil, underground services, and weather conditions should be developed and made available for all concerned parties.

- The registration of consulting companies and contractors should be reviewed from time to time to ensure the competence of their present technical and financial capabilities.

- The client should prepare a well-defined brief document about his/her needs before entering the design stage. This can be done either by carrying out a feasibility study or circulating a questionnaire to the end users of the project and also conduct enough deliberation about the project's final intended use.

- Clients should hire well-experienced technical staff members that can advise and help in decision making on a timely manner.

- Unlike what happened during the sudden rise in oil prices, the government should plan the projects in a fashion that does not lead to the contractors being overloaded by the number of projects with a shortage of qualified staff, especially engineers, which adversely affect the quality and time scheduling of works.

Further study can be conducted as:

- Similar studies can be done for other types of construction projects, such as road construction, utility, building construction, dam construction, and public construction.

- Detailed studies can be done in order to evaluate the involvement and effect of a specific party or resource of construction project on change orders in construction projects. 


\section{ACKNOWLEDGMENT}

This research was funded by the Deanship of Scientific Research at the University of Hail, Saudi Arabia, under the contract (E-7A-CE).

\section{REFERENCES}

[1] N. A. Kartam, S. A. Kartam, "Risk and its management in the Kuwaiti construction industry: a contractors' perspective", International Journal of Project Management, Vol. 19, No. 6, pp. 325-335, 2001

[2] N. A. W. A. Zawawi, N. F. I. N. Azman, S. Kamar, M. Shamil, "Sustainable construction practice: a review of change orders (CO) in construction projects", International Conference on Environment, Pulau Pinang, Malaysia, December 13-15, 2010

[3] Z. Osman, A. Omran, C. K. Foo, "The potential effects of variation orders in construction projects", Journal of Engineering, Vol. 7, pp. 141152,2009

[4] I. Rashid, M. Elmikawi, A. Saleh, "The impact of change orders on construction projects sports facilities case study", Journal of American Science, Vol. 8, No. 8, pp. 628-631, 2012

[5] N. T. I. Homaid, A. I. Eldosouky, M. A. Al-Ghamdi, "Change orders in Saudi linear construction projects", Emirates Journal for Engineering Research, Vol. 16, No. 1, pp. 33-42, 2011

[6] P. F. Kaming, P. O. Olomlaiye, G. D. Holt, F. C. Harris, "Factors influencing construction time and cost overruns on high-rise projects in Indonesia", Construction Management and Economics, Vol. 15, No. 1, pp. 83-94, 1997

[7] D. W. M. Chan, M. M. Kumaraswamy, "A comparative study of causes of time overruns in Hong Kong construction projects", International Journal of Project Management, Vol. 15, No. 1, pp. 55-63, 1997

[8] A. H. Al-Momani, "Construction delay: a quantitative analysis", International Journal of Project Management, Vol. 18, No. 1, pp. 51-59, 2000

[9] H. Goudreau, "The five key elements of a construction contract-Forget them and you are in trouble", available at: www.hgassociates.com/ articlecontracts.html, 2001

[10] A. M. Odeh, H. T. Battaineh, "Causes of construction delay: traditional contracts", International Journal of Project Management, Vol. 20, No. 1, pp. $67-73,2002$

[11] Z. A. Memon, "Remedial measure for delays at construction stage", Mehran University Research Journal of Engineering and Technology, Vol. 23, No. 1, pp. 9-20, 2004

[12] N. K. Acharya, Y. D. Lee, H. M. Im, "Conflicting factors in construction projects: Korean perspective", Engineering, Construction and Architectural Management, Vol. 13, No. 6, pp. 543-566, 2006

[13] M. Sambasivan, Y. W. Soon, "Causes and effects of delays in Malaysian construction industry", International Journal of Project Management, Vol. 25, No. 5, pp. 517-526, 2007

[14] C. O. Arun, B. N. Rao, "Knowledge based decision support tool for duration and cost overrun analysis of highway construction projects", Journal of The Institution of Engineers (India), Part AG, Vol. 88, pp. 27-33, 2007

[15] S. A. Assaf, S. Al-Hejji, "Causes of delay in large construction projects", International Journal of Project Management, Vol. 24, pp. 349-357, 2006

[16] C. Wu, T. Hsieh, W. Cheng, "Statistical Analysis of Causes for Design Change in Highway Construction in Taiwan", International Journal of Project Management, Vol. 23, No. 7, pp. 554-563, 2005

[17] J. H. Chen, S. C. Hsu, "Hybrid ANN-CBR model for disputed change orders in construction projects", Automation in Construction, Vol. 17, No. 1, pp. 56-64, 2007

[18] A. S. Alnuaimi, R. A. Taha, M. Al-Mohsin, A. S. Al-Harthi, "Causes, effects, benefits, and remedies of change orders on public construction projects in Oman", Journal of Construction Engineering and Management, Vol. 136, No. 5, pp. 615-622, 2010

[19] A. Alaryan, E. Beltagi, A. Elshahat, M. Dawood, "Causes and effects of change orders on construction projects in Kuwait", International Journal of Engineering Research and Applications, Vol. 4, No. 7 (Version 2), pp. $1-8,2014$

[20] S. Ahmed, A. H. Memon, N. A. Memon, A. N. Laghari, M. A. Akhund, H. U. Imad, "Common factors of cost escalation in construction industry of Pakistan", Engineering, Technology \& Applied Science Research, Vol. 8, No. 6, pp. 3508-3511, 2018

[21] F. A. Soomro, M. J. Memon, A. F. Chandio, S. Sohu, R. Soomro, "Causes of time overrun in construction of building projects in Pakistan”, Engineering, Technology \& Applied Science Research Vol. 9, No. 1, pp. 3762-3764, 2019

[22] I. Mahamid, A. Bruland, N. M. Dmaidi, "Causes of delay in road construction projects", Journal of Management in Engineering, Vol. 28, No. 3, pp. 300-310, 2012

[23] D. L. Harnett, J. Murphy, Introductory statistical analysis, AddisonWesley Publishing Company, 1975

\section{AUTHORS PROFILE}

Walid M. A. Khalifa received his BSc in Civil Engineering from Cairo University of Egypt in 1988, and his $\mathrm{PhD}$ in Water Resources and Environmental Hydrology from Cairo University in 2000. He is currently an assistant professor in Hail University, Saudi Arabia, and Fayoum University, Egypt. His research interests include predictive water quality and hydrodynamics in surface water bodies and also in reinforced concrete water structures.

Ibrahim Mahamid received his BSc in Civil Engineering from Birzeit University of Palestine in 2001, and his $\mathrm{PhD}$ in Construction Engineering and Project Management from Norwegian University of Science and Technology (NTNU), Norway in 2011. He is currently an associate professor in Prince Mugrin University, Saudi Arabia. His research interests include construction management and surveying. 